\title{
The Nanosuspension Formulations of Daidzein: Preparation and In Vitro Characterization
}

\section{Daidzein Nanosüspansiyon Formülasyonları: Hazırlanması ve In Vitro Karakterizasyonu}

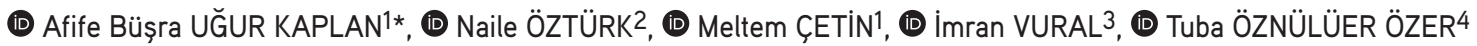 \\ ${ }^{1}$ Atatürk University Faculty of Pharmacy, Department of Pharmaceutical Technology, Erzurum, Turkey \\ 2Inönü University Faculty of Pharmacy, Department of Pharmaceutical Technology, Malatya, Turkey \\ 3Hacettepe University Faculty of Pharmacy, Department of Pharmaceutical Technology, Ankara, Turkey \\ ${ }^{4}$ Atatürk University Faculty of Science, Department of Chemistry, Erzurum, Turkey
}

\begin{abstract}
Objectives: Daidzein (DZ), a water-insoluble isoflavone, has many beneficial effects (anti-inflammatory, antioxidant, and anticancer effects, etc.) on human health. DZ has a very low oral bioavailability related to its physicochemical properties (low solubility, intense metabolism of DZ in the intestine and liver). This study aimed to prepare and in vitro characterize the nanosuspension formulations of DZ to improve the poor solubility and efficacy of DZ.

Materials and Methods: DZ nanosuspension formulations were prepared with media milling technique using zirconium oxide beads as milling media. Pluronic F127 and polyvinylpyrrolidone (PVP) K30 (formulation A; F-A) and sodium dodecyl sulfate (SDS) (SDS + pluronic F127 + PVP K30; formulation B; F-B) were used as stabilizers. The nanosuspension formulations were evaluated for morphological properties, particle sizes, zeta potential, DZ content, saturation solubility, dissolution, and their cytotoxic effects on RG2 glioblastoma tumor cells.

Results: F-A and F-B formulations were nanosized (in the range of about $181-235 \mathrm{~nm}$ ) and had negative zeta potential values before and after lyophilization. The DZ content of F-A and F-B formulations were found to be $93.68 \pm 0.78 \%$ and $89.75 \pm 0.49 \%$, respectively. Fourier transform infrared spectroscopy analysis showed that there was no significant interaction between DZ and the excipients. Differential scanning calorimetry and X-ray diffraction analyses confirmed no change in the crystal structure of DZ in F-A and F-B formulations.

Conclusion: In this study, the nanosuspension formulations were successfully prepared and characterized in vitro. Nanosuspension formulations increased the saturation solubility, dissolution rate, and cytotoxic effect of DZ.
\end{abstract}

Key words: Cytotoxicity, daidzein, FTIR analysis, nanosuspension, media milling

öz

Amaç: Suda çözünmeyen bir izoflavon olan daidzein (DZ), insan sağlığı üzerinde pek çok faydalı etkiye (anti-inflamatuvar, antioksidan ve antikanser etkileri vb.) sahiptir. DZ, fizikokimyasal özelliklerine (düşük çözünürlük, bağırsakta ve karaciğerde DZ'nin yoğun metabolizasyonu) bağlı olarak çok düșük bir oral biyoyararlanıma sahiptir. Bu çalıșmanın amacı, DZ'nin zayıf çözünürlüğünü ve etkinliğini iyileștirmek üzere DZ'nin nanosüspansiyon formülasyonunu hazırlamak ve in vitro olarak karakterize etmektir.

Gereç ve Yöntemler: DZ nanosüspansiyon formülasyonları, öğütme ortamı olarak zirkonyum oksit boncukları kullanılarak yaş öğütme tekniği ile hazırlandı. Stabilizan olarak pluronic F127 ve polivinilpirolidon (PVP) K30 (formülasyon A; F-A) ve sodyum dodesil sülfat (SDS) (SDS + pluronic F127 + PVP K30; formülasyon B; F-B) kullanıldı. Nanosüspansiyon formülasyonları, morfolojik özellikleri, partikül boyutları, zeta potansiyel, DZ içeriği, doygunluk çözünürlüğü, çözünme ve RG2 glioblastoma tümör hücreleri üzerindeki sitotoksik etkileri açısından değerlendirildi.

Bulgular: Liyofilizasyon öncesi ve sonrası, F-A ve F-B formülasyonları nano-boyutluydular (yaklaşık 181-235 nm aralığında) ve ayrıca negatif

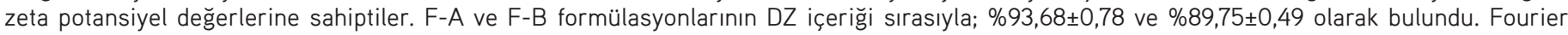
dönüşümlü kızıötesi analizi, DZ ve yardımcı maddeler arasında önemli bir etkileşim olmadığını gösterdi. Diferansiyel taramalı kalorimetre ve X-ışını difraktometresi analizleri, F-A ve F-B formülasyonlarında DZ'nin kristal yapısında hiçbir değişiklik olmadığını doğruladı.

Sonuç: Bu çalışmada, nanosüspansiyon formülasyonları başarıyla hazırlandı ve in vitro olarak karakterize edildi. Nanosüspansiyon formülasyonları DZ'nin doygunluk çözünürlügünü, çözünme hızını ve sitotoksik etkisini artırdı.

Anahtar kelimeler: Sitotoksisite, daidzein, FTIR analizi, nanosüspansiyon, yaş öğütme 


\section{INTRODUCTION}

About $10 \%$ of the drugs in the clinical use and $40 \%$ of the newly developed drugs are poorly water-soluble. The poor solubility of active substances leads to poor bioavailability and limits their potential pharmacological effects. Therefore, increasing the aqueous solubility of poorly soluble active substances is critical. There are many approaches such as the use of cosolvents, salt formation, $\mathrm{pH}$ adjustment and the preparation of solid dispersions, inclusion complexes, nanosized dosage forms (nanosuspension, micelles, nanoliposome, microemulsion, etc.) to overcome the problem. ${ }^{1,2}$ Nanosizing is a promising and popular approach to improve the solubility and bioavailability of hydrophobic active substances. ${ }^{3,4}$ According to the NoyesWhitney equation, the dissolution rate and bioavailability of a hydrophobic active substance increases with reducing the particle size and hence increasing the surface area of the particle. 'Additionally, as theoretically confirmed by the OstwaldFreundlich equation, the surface area and the saturation solubility of the particle increase with decreasing the particle size to the nanometer range. ${ }^{2}$

Nanosuspensions are colloidal dispersions of nanosizedparticles (generally, the mean particle size: 200-600 nm), stabilized with stabilizers (surfactants, polymers, or their combination). 3.5 Especially, nanosuspensions are convenient formulations for the active substances with high log $P$ value, high dose, and high melting point to increase the bioavailability of such active substances, reduce their dose and, obtain stable formulations as the selection of proper stabilizers. ${ }^{6,7}$ Nanosuspension formulation leads to reduce the administered dose of active substance and its side effects/toxicity by improving the bioavailability of the active substances. Nanoscale size and hence greatly increased surface area of particles are responsible for the physical instability of nanosuspensions. The increased surface area leads to high interfacial tension, increasing the free energy of the system. Therefore, nanosuspension is not essentially thermodynamically stable system. ${ }^{7,8}$ To reduce the system's free energy by decreasing interfacial tension, stabilizers are used in the formulation. The stabilizers [polyvinylpyrrolidone (PVP), Tween 80, polyvinyl alcohol, sodium lauryl sulfate, poloxamers, etc.] prevent nanoparticle aggregation by steric or electrostatic stabilization. ${ }^{8}$ Currently, there are many nanosuspension products of poorly soluble active substances in the market, and many nanosuspension formulations are also under development. ${ }^{9}$

DZ(7-hydroxy-3-(4-hydroxyphenyl)-4H-chromen-4-one) mainly present in soy bean and soy products. DZ, a waterinsoluble isoflavone, is a potent antioxidant and enzyme inhibitor. It also inhibits cytokines, cell adhesion proteins and platelet aggregation, induces nitric oxide production and reduces lowdensity lipoprotein cholesterol levels. ${ }^{10,11}$ DZ has many beneficial effects (anti-inflammatory activities, anticancer effect, prevention of the onset of diabetes, prevention and treatment of cardiovascular diseases and prevention of bone loss after menopause, etc.) on human health as mentioned in previous studies. ${ }^{10-13}$ The cytotoxic effects of DZ were investigated in different cancer cells (neuroblastoma, glioma, melanoma, and pancreatic carcinoma cells, colon, prostate, cervical cancer cells, etc.) and it has anti-carcinogenic properties. ${ }^{10,14-17} \mathrm{DZ}$ has very low oral bioavailability related to its physicochemical properties (low solubility, intense metabolism of DZ in the intestine, and liver), limiting its potential bioactivities for human health. It was reported that the absolute bioavailability of DZ was $6.1 \%$ after the oral administration of the suspension of DZ to rats.11,18 DZ-loaded poly(lactide-co-glycolide) nanoparticles, or lipid nanocarriers, or chitosan microspheres for different application routes, DZ-cocrystals, and DZ-cyclodextrin-polymer complexes were prepared to resolve the problems such as the poor solubility and low bioavailability of DZ.11-13,19-21

Glioblastoma (GBM), the most common primary malignant tumor, accounts for about $30 \%$ of all central nervous system tumors. GBM constitutes $2.3 \%$ of all cancer-related deaths each year. In spite of some clinical trials in the past decade, improvement in the therapy of GBM has been insufficient. Although there is a multimodal approach consisting of surgery followed by radiotherapy and chemotherapy for GBM treatment, the average overall survival time of all patients with GBM is 1215 months; only, the survival time of $\langle 5 \%$ of patients with GBM is longer than 5 years. ${ }^{22}$

In a study, the antitumor effects of DZ on neuroblastoma cells were investigated, and it was found that DZ inhibits cell proliferation by preventing cell cycle progression. ${ }^{14}$ The intrinsic apoptotic pathway is modulated by $\mathrm{DZ}$, and $\mathrm{Bcl}-2$ plays a fundamental role in malignant glioma cell death mediated by the combination of tumor necrosis factor-related apoptosisinducing ligand (TRAIL) and DZ. ${ }^{23}$

Zhang et al. ${ }^{24}$ evaluated the inhibitory effects of daid002, a novel DZ derivative, on GBM cells (U87MG) proliferation. They reported that GBM growth was inhibited by daid002, and it induced G0/G1 phase arrest.

This study aimed to prepare and in vitro characterize nanosized-DZ for nanosuspension formulation to improve the poor solubility and efficacy of DZ. Also, its cytotoxic effect was evaluated using rat glioma 2 (RG2) GBM tumor cells.

\section{MATERIALS AND METHODS}

\section{Materials}

In this study, DZ (LC Laboratories, USA), pluronic F127 (BASF, Brenntag Canada Inc., Canada), PVP-K30 (Santa-Farma Ilaç Sanayi A.Ș., Turkey), sodium dodecyl sulfate (SDS) (SantaFarma Illaç Sanayi A.Ș., Turkey), thiazolyl blue tetrazolium bromide (MTT) (AppliChem GmbH, Darmstadt, Germany), $\mathrm{N}, \mathrm{N}$-dimethylformamide (DMF) (Sigma-Aldrich, Taufkirchen, Germany), dimethylsulfoxide (DMSO) (Lab-Scan, Ireland), Dulbecco's modified Eagle's medium (DMEM)/Ham's F12 (Biochrom, Berlin, Germany), L-glutamine (Biochrom, Berlin, Germany), fetal bovine serum (Biochrom, Berlin, Germany), penicillin (Biochrom, Berlin, Germany) and streptomycin (Biochrom, Berlin, Germany) were used. 


\section{Preparation of formulations}

DZ nanosuspension formulations were prepared with media milling technique from coarse DZ using zirconium oxide beads as milling media and pluronic F127 and PVP K30 (formulation $A ; F-A$ ) and SDS (SDS + pluronic F127 + PVP K30; formulation B; F-B) as stabilizers (Table 1).

Table 1. Content of the formulations

\begin{tabular}{lll} 
Ingredients & $\begin{array}{l}\text { Formulation A } \\
\text { (F-A) }\end{array}$ & $\begin{array}{l}\text { Formulation B } \\
\text { (F-B) }\end{array}$ \\
\hline DZ & $50 \mathrm{mg}$ & $50 \mathrm{mg}$ \\
\hline Pluronic F127 & $1 \%(\mathrm{w} / \mathrm{v})$ & $1 \%(\mathrm{w} / \mathrm{v})$ \\
\hline PVP K30 & $1 \%(\mathrm{w} / \mathrm{v})$ & $1 \%(\mathrm{w} / \mathrm{v})$ \\
\hline SDS & - & $0.5 \%(\mathrm{w} / \mathrm{v})$ \\
\hline Ultrapure water & $5 \mathrm{~mL}$ & $5 \mathrm{~mL}$ \\
\hline
\end{tabular}

DZ: Daidzein, PVP: Polyvinylpyrrolidone, SDS: Sodium dodecyl sulfate

Coarse DZ was dispersed in a $10 \mathrm{~mL}$ glass vial containing the stabilizers' aqueous solution and zirconium oxide beads (diameter: 0.3-0.4 mm). Comminution was carried out on a magnetic stirrer at $1200 \mathrm{rpm}$ for $24 \mathrm{~h}$ at room temperature as determined by preliminary studies. After the beads were removed by decantation, the obtained nanosuspensions were centrifuged at $12,500 \mathrm{rpm}$ for $40 \mathrm{~min}$. Then, the prepared DZ nanosuspension formulations were lyophilized for $24 \mathrm{~h}\left(-55^{\circ} \mathrm{C}\right.$, 0.021 mbar; Martin Christ, Alpha 1-2 LD plus).

\section{Characterization of the prepared formulations}

\section{Particle size and zeta potential}

The mean particle size, polydispersity index (PDI) and, zeta potential of the formulations (F-A and F-B) were determined by Zetasizer Nano ZSP (Malvern Ins. Ltd, UK). Measurements were performed before and after lyophilization at $25^{\circ} \mathrm{C}$. Samples $(n=6)$ were diluted with ultrapure water to obtain a suitable concentration for measurement. Moreover, Mastersizer Hydro 2000 MU (Malvern Ins. Ltd., UK) was used to determine the particle size of coarse DZ due to its micron size. The results were expressed in mean \pm standard error (SE).

\section{Morphological analysis}

The morphological features of coarse DZ and the lyophilized nanosuspension formulations ( $\mathrm{F}-\mathrm{A}$ and $\mathrm{F}-\mathrm{B}$ ) were examined using scanning electron microscope [(SEM), Zeiss Sigma 300 , Germany] at an acceleration voltage of $5 \mathrm{kV}$ and different magnifications. Before analysis, samples were fixed to metal plates and coated with gold under vacuum to increase conductivity.

\section{Fourier transform infrared spectroscopy (FTIR) analysis}

FTIR analysis of coarse DZ, stabilizers (pluronic F127, PVP $\mathrm{K} 30$, and SDS), the lyophilized nanosuspension formulations (F-A and F-B) was carried out in the region of $4000-400 \mathrm{~cm}^{-1}$ and under vacuum by using FTIR (Perkin Elmer Spectrum One FTIR spectrometer, Germany).

\section{Differential scanning calorimetry (DSC) analysis}

DSC analyzes of coarse DZ, stabilizers (pluronic F127, PVP $\mathrm{K} 30$, and SDS), the lyophilized nanosuspension formulations ( $\mathrm{F}-\mathrm{A}$ and $\mathrm{F}-\mathrm{B}$ ) were performed at $25-400^{\circ} \mathrm{C}$ with a heating rate of $10^{\circ} \mathrm{C} / \mathrm{min}$ in air atmosphere using DSC (Netzsch STA 409 PC Luxx ${ }^{\circledast}$, Germany) to determine their thermal properties. Alumina pans were used for samples.

\section{$X$-ray diffraction $(X R D)$ analysis}

XRD analysis of coarse DZ, stabilizers (pluronic F127, PVP K30, and SDS), the lyophilized nanosuspension formulations (F-A and F-B) were carried out using Rigaku Miniflex diffractometer (Japan) using $\mathrm{Cu} K \alpha$ radiation (1.5406 $\AA$ ) with a divergence slit $1.25^{\circ}$. The XRD data for the samples were collected between $5^{\circ}$ and $90^{\circ}$. Percentage crystallinity of the materials was calculated using XRD deconvolution method using origin software.

\section{DZ content}

The lyophilized formulations (F-A and F-B) was dissolved in DMSO by mixing for 15 min to determine the DZ content. Later, the samples were filtered using a membrane filter [polytetrafluoroethylene (PTFE); pore size:220 nm], and DZ content was determined using a validated high performance liquid chromatography (HPLC)-ultraviolet (UV) method [HPLC conditions: Stationary phase: $C_{18}$ column (Diamonsil $5 \mu \mathrm{m}$, $200 \times 4.6 \mathrm{~mm}$ ) and guard column (EasyGuard $\mathrm{C}_{18}$ 10x4 mm), mobile phase: methanol: ultrapure water (60:40), flow rate: 1 $\mathrm{mL} / \mathrm{min}$, UV detection: $249 \mathrm{~nm}$, injection volume: $10 \mu \mathrm{L}$ ].

\section{Saturation solubility}

Saturation solubility of coarse DZ and the lyophilized nanosuspension formulations ( $F-A$ and $F-B$ ) were evaluated in six different media $[\mathrm{HCl}-\mathrm{pH}$ 1.2; phosphate buffer (PB) - $\mathrm{pH}$ 6.8, and 7.4; $\mathrm{HCl}+5 \%$ Tween $80-\mathrm{pH} 1.2 ; \mathrm{PB}+5 \%$ Tween 80 - pH 6.8, and 7.4 (PB)]. An excess amount of coarse DZ and the formulations ( $F-A$ and $F-B$ ) were dispersed in the suitable medium and shaken continuously for $24 \mathrm{~h}$ in a water bath at $37 \pm 0.5^{\circ} \mathrm{C}$. After centrifugation at $12,500 \mathrm{rpm}$ for $15 \mathrm{~min}$, the obtained supernatants were filtered using a membrane filter [polyvinylidene fluoride (PVDF); pore size: $220 \mathrm{~nm}$ ]. Then, DZ concentration in samples was determined using a validated HPLC-UV method (at $249 \mathrm{~nm}$ ).

\section{Dissolution studies}

Dissolution studies for coarse DZ and the lyophilized nanosuspension formulations (F-A and F-B) were conducted in $500 \mathrm{~mL}$ of three different dissolution media $(\mathrm{HCl}+5 \%$ Tween $80-\mathrm{pH}$ 1.2; PB + 5\% Tween $80-\mathrm{pH}$ 6.8, and 7.4) using USP dissolution apparatus 2 (paddle method) (Pharma Test PTWS IIIE/CE, Germany). During the dissolution experiment, the temperature was maintained at $37 \pm 0.5^{\circ} \mathrm{C}$, using a paddle speed of 100 rpm. $5-\mathrm{mL}$ samples were withdrawn at predetermined time intervals, and an equal volume of fresh dissolution medium was added to the dissolution vessel to maintain Sink condition. After centrifugation at $12,500 \mathrm{rpm}$ for $15 \mathrm{~min}$, the obtained supernatants were filtered using a membrane filter (PVDF, pore size: $220 \mathrm{~nm}$ ). Then, DZ concentration in samples was determined using a validated HPLC-UV method (at $249 \mathrm{~nm}$ ). 


\section{Cell culture study}

To evaluate the effects of coarse DZ and the nanosuspension formulations ( $F-A$ and $F-B$ ) on the viability of RG2 cell line (American Type Culture Collection, Manassas, VA, USA), MTT assay was used. 1:1 mixture of DMEM/Ham's F12 supplemented with $2.5 \mathrm{mM} \mathrm{L-glutamine,} \mathrm{10 \%} \mathrm{fetal} \mathrm{bovine} \mathrm{serum,} \mathrm{penicillin} \mathrm{(50}$ units $/ \mathrm{mL}$ ), and streptomycin $(50 \mu \mathrm{g} / \mathrm{mL})$ was used as culture medium. RG2 cells were seeded in 96 -well plates $\left(5 \times 10^{3}\right.$ cells per well) and were incubated overnight at $37^{\circ} \mathrm{C}$ in $5 \% \mathrm{CO}_{2}$. After incubation, the cells were treated with DZ solution in a culture medium containing 0.5\% DMSO (AppliChem GmbH, Darmstadt, Germany), the suspension of coarse DZ and the nanosuspensions of F-A, and F-B formulations prepared in the culture medium, and the solutions of the excipients (Exp F-A: Pluronic F127, and PVP K30) used in formulation $A$ and formulation $B$ (Exp F-B: Pluronic F127, PVP K30, and SDS) prepared in the culture medium. In this experiment, DZ concentrations were used in the range of $50-400 \mu \mathrm{M}$. After 24 and $48 \mathrm{~h}$ incubation, $25 \mu \mathrm{L}$ of MTT solution $(5 \mathrm{mg} / \mathrm{mL}$ ) was added per well. $4 \mathrm{~h}$ later, $80 \mu \mathrm{L}$ of $23 \%$ SDS solution in DMF: water (45:55, v/v) was added to each well and the plates were incubated overnight at $37^{\circ} \mathrm{C}$ in $5 \% \mathrm{CO}_{2}$. After incubation, absorbance (at $570 \mathrm{~nm}$ ) was measured using a microplate reader to assess cell viability.

\section{Statistical analysis}

SPSS Statistics Version 22.0 (SPSS Inc., Chicago, USA) was used to perform statistical analysis. An independent t-test was used to evaluate the significance of the difference between two independent groups. The difference was accepted to be significant if $p<0.05$.

\section{RESULTS AND DISCUSSION}

Nanosuspension formulation has been developed to improve the poor solubility and low bioavailability of poorly water-soluble active substances/compounds by reducing their particle size. Consequently, the formulation alters the pharmacokinetics of these active substances/compounds and improve their efficacy and safety. 7,25 In our study, we prepared and characterized DZ nanosuspension formulations (F-A and F-B).

\section{The particle sizes of coarse $D Z, F-A$, and $F-B$ formulations}

The mean particle sizes, and PDI values of F-A and F-B are shown in Figure 1. Also, the d10, d50, d90, and span values of coarse DZ are given in Table 2. Coarse DZ was micron in size, and $\mathrm{d} 50$ and $\mathrm{d} 90$, which correspond to the particle diameter at $50 \%$ and $90 \%$ of the total volume, were found to be $55.545 \pm 1.473$ and $164.561 \pm 7.941 \mu \mathrm{m}$, respectively (Table 2). However, it was found that both formulations ( $F-A$ and $F-B$ ) were nanosized (in the range of about 181-235 $\mathrm{nm}$ ) (Figure 1a). The mean particle size of the F-A formulation was smaller than those of the F-B formulation. Before lyophilization, the difference between particle sizes of F-A and F-B was significant ( $p<0.05$ ), but after lyophilization, the difference was not significant ( $p>0.05$ ). Also, the particle sizes of both formulations increased significantly after lyophilization ( $p<0.05$ ), but their particle sizes were still nanosize range (Figure 1a). Lyophilization without cryo- and a
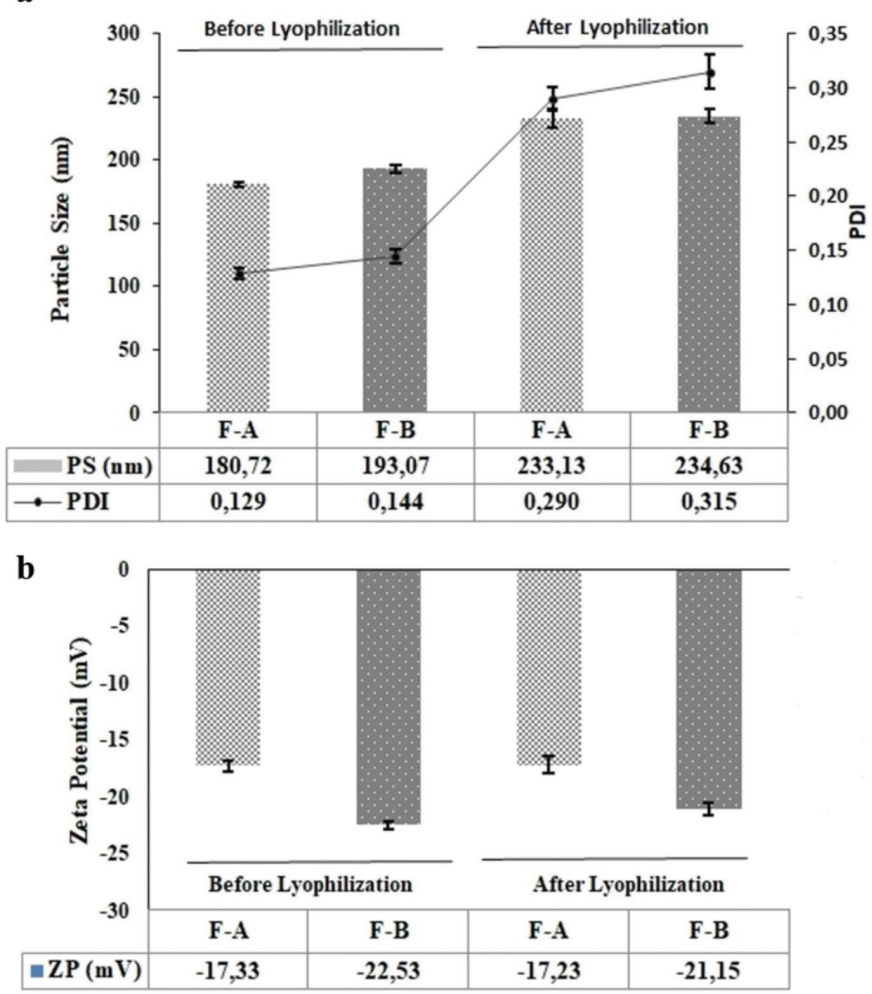

Figure 1. The particle size (PS), PDI and zeta potential (ZP) values of F-A and F-B formulations $(n=6$, mean \pm SE). SE: Standard error, PDI: Polydispersity index

Table 2. Mean droplet size and span values of coarse DZ Mean Diameter $(\mu \mathrm{m})$

\begin{tabular}{llll}
\hline$d_{10}$ & $d_{50}$ & $d_{90}$ & Span \\
$18.490 \pm 0.617$ & $55.545 \pm 1.473$ & $164.561 \pm 7.941$ & $2.633 \pm 0.162$ \\
\hline
\end{tabular}

$(n=3$, mean \pm SE). DZ: Daidzein, SE: Standard error

lyoprotectant or in the presence of a low concentration of cryoand lyoprotectant increases particle size due to aggregation. 26,27

Furthermore, the PDI values of formulations (F-A and F-B) were less than 0.2 before lyophilization and approximately 0.3 after lyophilization; therefore, the prepared formulations (F-A and $F-B$ ) have narrow particle size distribution. The particle size, and PDI are very critical factors for the physical stability of colloidal dispersions. PDI value less than 0.3 is acceptable and indicates monodispersity for colloidal dispersions. ${ }^{23}$

\section{The zeta potentials of $F-A$ and $F-B$ formulations}

Zeta potential is an essential parameter for the physical stability of colloidal dispersions. Non-ionic surfactants/stabilizers and negative zeta potential prevent the aggregation of the particles by creating steric and electrostatic hindrances. Hence, the physical stability of nanosized dispersions is increased. ${ }^{28,29}$ In the case of a combined steric and electrostatic stabilization, a zeta potential of at least about $\pm 20 \mathrm{mV}$ is acceptable. ${ }^{30}$

In this study, it was found that F-A and F-B had negative zeta potential values [in the range of (-) 17.23- (-) $22.53 \mathrm{mV}$ ] before 
and after lyophilization (Figure 1b). Due to the presence of SDS (anionic surfactant) in the F-B formulation, the zeta potential of F-B was greater than the zeta potential of F-A ( $p<0.05)$. Besides, lyophilization did not cause a significant change in the zeta potential values of both formulations ( $p>0.05$ ).

The morphological analyzes of coarse DZ, F-A and F-B formulations

SEM images were obtained for the morphological analysis of coarse DZ and F-A and F-B formulations (Figure 2). We observed that the coarse DZ particles were non-uniform and rod-like micron-sized particles (Figure 2a), in contrast, the F-A and $\mathrm{F}-\mathrm{B}$ formulations had an approximately uniform shape and nano-sized distribution (Figure 2b, 2c).

The results of FTIR, DSC, and XRD analyze

FTIR analysis is performed to identify the compound's structural properties by determining the vibration characteristics of functional groups. It is also used to determine the interactions among the active compound(s) and other formulation components. ${ }^{29}$

FTIR spectra of coarse DZ, pluronic F127, PVP K30, SDS, and $\mathrm{F}-\mathrm{A}$ and $\mathrm{F}-\mathrm{B}$ formulations are given in Figure 3 . In the FTIR spectrum of DZ, several characteristics peaks at about $3225 \mathrm{~cm}^{-1}$ (assigned to $-\mathrm{OH}$ group (intermolecular) stretching vibration), $2834 \mathrm{~cm}^{-1}$ (due to $-\mathrm{CH}$ stretching vibrations), 1630 $\mathrm{cm}^{-1}$ (assigned to $-\mathrm{C}=\mathrm{O}$ stretching vibrations) and $1598 \mathrm{~cm}^{-1}$ (corresponding to $-\mathrm{C}=\mathrm{C}$ vibration) (Figure 3). Similar data were reported by Bhalla et al. ${ }^{21}$ When the FTIR spectra of coarse DZ, F-A and F-B formulations were examined, the FTIR spectra of F-A and F-B formulations (characteristic peaks related to DZ with different intensities were seen) were similar to the spectrum of coarse DZ. It showed that there was no significant interaction between $\mathrm{DZ}$ and the excipients. Consequently, the chemical structure of the DZ was preserved in the F-A and F-B formulations.

In this study, DSC analysis was performed to determine the thermal properties of the active compound and to examine the possible interactions among active compound and excipients in the formulation. The thermograms of the coarse DZ, pluronic F127, PVP K30, SDS, F-A, and F-B formulations are given in Figure 4. A sharp endothermic peak at about $338^{\circ} \mathrm{C}$ was seen in the thermogram of $D Z$ (Figure 4). This characteristic peak is related to DZ's melting point (in the range of $330-340^{\circ} \mathrm{C}$ ). $10,31,32$ The thermograms of F-A and F-B formulations exhibited the characteristic peak related to the melting point of DZ (Figure 4); as a result, DSC analysis showed that the crystallinity of DZ was maintained in both formulations.

Besides, XRD analysis of the coarse DZ, pluronic F127, PVP K30, SDS, F-A, and F-B formulations were performed, and the results are given in Figure 5. This analysis was used to identicate the structure at the crystalline lattice level. ${ }^{33}$ There were peaks at $2 \theta$ values of $6.9^{\circ}, 8.5,10.4,12.9,15.9,17.0,24.6,25.3,26.5,28.1$, and 28.8 in the XRD patterns of coarse DZ (Figure 5). These results are consistent with a previously published study. ${ }^{33}$ The XRD patterns of F-A and F-B formulations were similar to the XRD patterns of coarse DZ (Figure 5). In our study, it was shown that the crystal structure of DZ was preserved in both formulations.

As a result, DSC and XRD analyzes confirmed no change in the crystal structure of DZ in F-A and F-B formulations.

\section{$D Z$ content of $F-A$ and $F-B$ formulations}

The DZ content of F-A and F-B formulations were found to be $93.68 \pm 0.78 \%$ and $89.75 \pm 0.49 \%$ (mean $\pm S E, n=6$ ), respectively. The negligible loss of DZ might be associated with the loss occurring during the preparation process of nanosuspension. ${ }^{34}$ There was a slight reduction in the DZ content of $\mathrm{F}-\mathrm{B}$

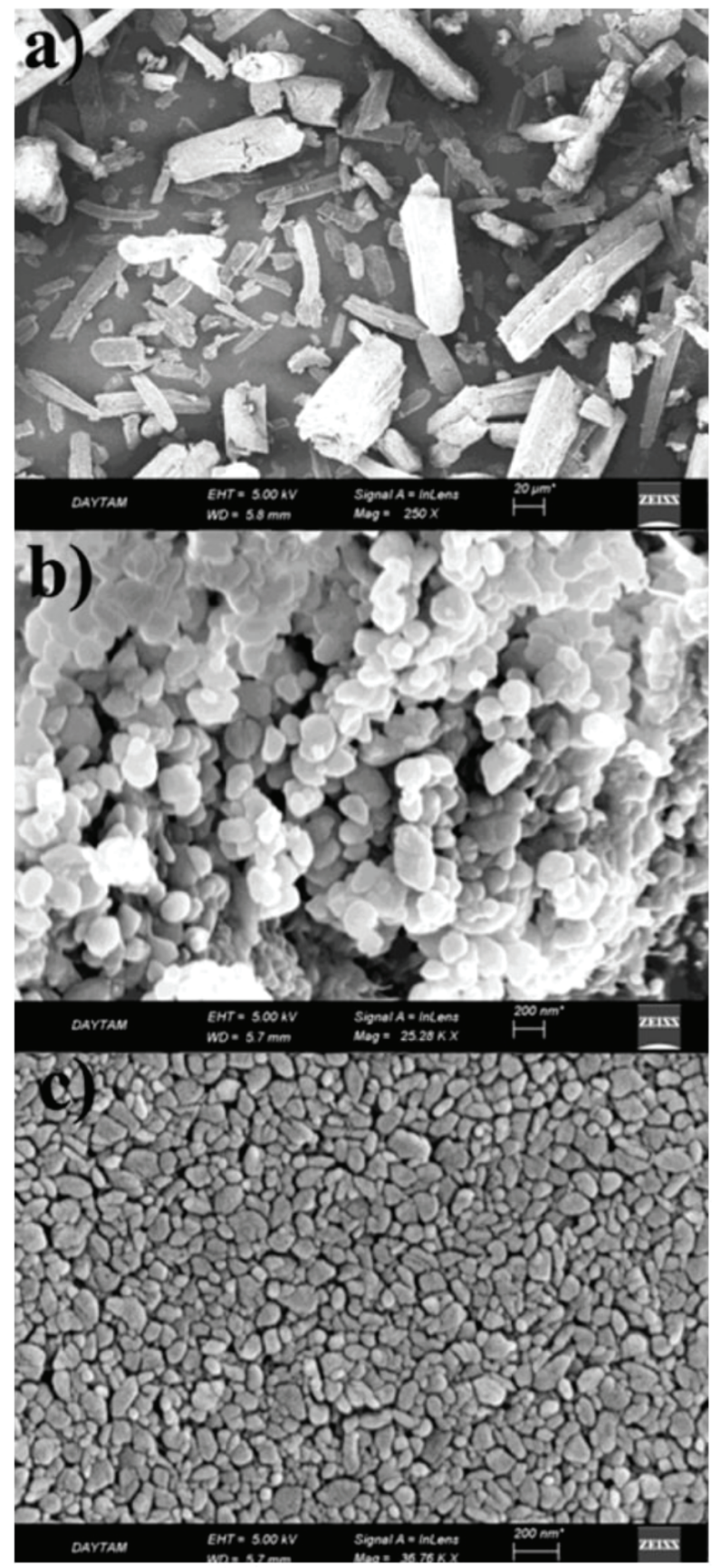

Figure 2. SEM images of coarse DZ (a), F-A (b) and F-B (c) formulations SEM: Scanning electron microscope, DZ: Daidzein 


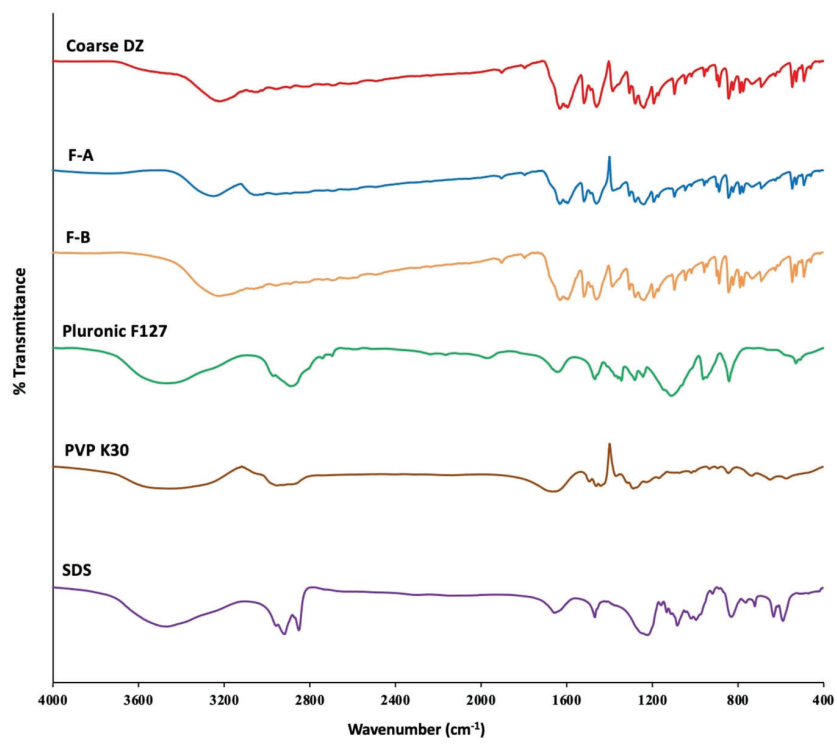

Figure 3. FTIR spectra of coarse DZ, F-A and F-B formulations, and the excipients in the formulation (pluronic F127, PVP K30, and SDS)

FTIR: Fourier transform infrared spectroscopy, DZ: Daidzein, PVP: Polyvinylpyrrolidone, SDS: Sodium dodecyl sulfate

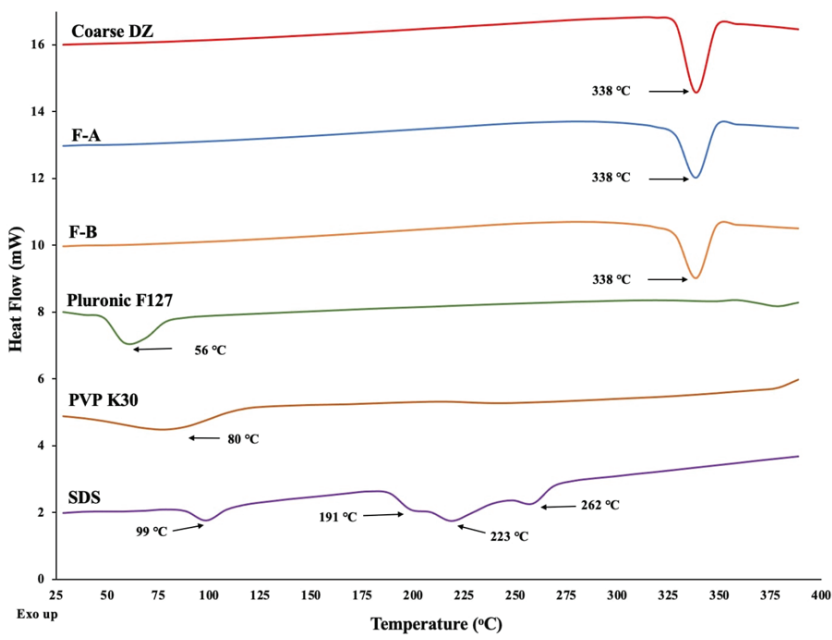

Figure 4. DSC thermograms of coarse DZ, F-A and F-B formulations, and the excipients in the formulation (pluronic F127, PVP K30, SDS)

DSC: Differential scanning calorimetry, DZ: Daidzein, PVP: Polyvinylpyrrolidone, SDS: Sodium dodecyl sulfate formulation compared to that of F-A formulation $(p<0.05)$. This reduction in $\mathrm{F}-\mathrm{B}$ formulation can be attributed to the presence of SDS, which likely causes a slight increase in the solubility of DZ during the preparation of nanosuspension.

The saturation solubility of coarse $D Z, F-A$, and F-B formulations $\mathrm{DZ}$, which belonging to Biopharmaceutical Classification System class IV, has low solubility and poor bioavailability. ${ }^{35}$ Saturation solubility studies for coarse DZ, F-A and F-B formulations were conducted in the buffer solutions with different $\mathrm{pH}(\mathrm{pH} 1.2,6.8$, and 7.4 ) and with/without $5 \%$ Tween 80 . The solubility results, which are given in Table 3, indicated that coarse DZ, F-A, and $\mathrm{F}-\mathrm{B}$ formulations have a $\mathrm{pH}$-dependent solubility. Panizzon et al. ${ }^{35}$ reported that $\mathrm{DZ}$ has a higher solubility in alkaline $\mathrm{pH}$ compared to acidic and neutral $\mathrm{pH}$; thus, its solubility is $\mathrm{pH}$ dependent. In our study, the solubility of coarse $\mathrm{DZ}$ in the buffer solutions with different $\mathrm{pH}(\mathrm{HCl}-\mathrm{pH}$ 1.2; $\mathrm{PB}-\mathrm{pH}$ 6.8; and $\mathrm{PB}$ - $\mathrm{pH}$ 7.4) were found to be just $0.99 \pm 0.15 \mu \mathrm{g} / \mathrm{mL}, 1.81 \pm 0.06 \mu \mathrm{g} /$ $\mathrm{mL}$, and, $3.21 \pm 0.24 \mu \mathrm{g} / \mathrm{mL}$, respectively (Table 3). In F-A and $\mathrm{F}-\mathrm{B}$ formulations, the solubility of $\mathrm{DZ}$ in the different buffer solutions $(\mathrm{HCl}-\mathrm{pH} \mathrm{1.2;} \mathrm{PB}-\mathrm{pH}$ 6.8; and $\mathrm{PB}-\mathrm{pH} 7.4)$ increased in the range of about 6-14-fold in compared to coarse DZ ( $p<0.05$; Table 3 ). The saturation solubility of DZ increased in $\mathrm{F}-\mathrm{A}$ and F-B formulations due to the large specific surface area because of the particle size decreasing to the nanosize range.

Moreover, it is significant to ensure a sink condition in the dissolution/release medium. In sink conditions, the saturation solubility of an/a active substance/compound is at least 3 times more than its concentration in the dissolution/release medium. ${ }^{36}$ In the literature, to achieve sink condition in the study of dissolution/release, which was performed for the formulations genistein or DZ, the buffer solutions (PB or PBS $\mathrm{pH} 7.4$ ) with ethanol (30\%) or SDS (5\%) or methanol $(50 \%)$ or aqueous solutions with SDS (3\%) or Tween $80(0.5 \%)$ were used as release/dissolution medium..$^{10,37-40}$ Oliveira et al. ${ }^{38}$ evaluated the solubilities of genistein and daidzein in several different mediums (sodium acetate buffer $\mathrm{pH} 4.5$, water, water with $3 \%$ Tween 80 , water with $3 \%$ Tween 20 ; water with $3 \%$ SDS) to properly design the dissolution test.

In our study, the solubility of DZ was also evaluated in the different buffer solutions with Tween 80 (5\%) to properly

Table 3. The results of saturation solubility study

\begin{tabular}{llll} 
& Coarse-DZ $(\mu \mathrm{g} / \mathrm{mL})$ & $\mathrm{F}-\mathrm{A}(\mu \mathrm{g} / \mathrm{mL})$ & $\begin{array}{l}\mathrm{F}-\mathrm{B} \\
(\mu \mathrm{g} / \mathrm{mL})\end{array}$ \\
\hline $\mathrm{pH} 1.2 \mathrm{HCl}$ & $0.99 \pm 0.15$ & $7.94 \pm 1.00$ & $13.83 \pm 0.27$ \\
\hline $\mathrm{pH} 6.8 \mathrm{~PB}$ & $1.81 \pm 0.06$ & $11.95 \pm 1.00$ & $21.23 \pm 0.33$ \\
\hline $\mathrm{pH} 7.4 \mathrm{~PB}$ & $3.21 \pm 0.24$ & $17.39 \pm 1.16$ & $30.89 \pm 0.39$ \\
\hline $\mathrm{HCl}+5 \%$ Tween $80-\mathrm{pH} 1.2$ & $80.68 \pm 6.80$ & $102.16 \pm 6.36$ & $118.99 \pm 7.65$ \\
\hline $\mathrm{PB}+5 \%$ Tween $80-\mathrm{pH} 6.8$ & $107.06 \pm 5.54$ & $143.80 \pm 5.34$ & $159.53 \pm 7.02$ \\
\hline $\mathrm{PB}+5 \%$ Tween $80-\mathrm{pH} 7.4$ & $128.77 \pm 3.66$ & $150.04 \pm 2.01$ & $188.69 \pm 4.36$ \\
\hline
\end{tabular}

(Mean $\pm \mathrm{SE} ; \mathrm{n}=3$ ). PB: Phosphate buffer, SE: Standard error, DZ: Daidzein 


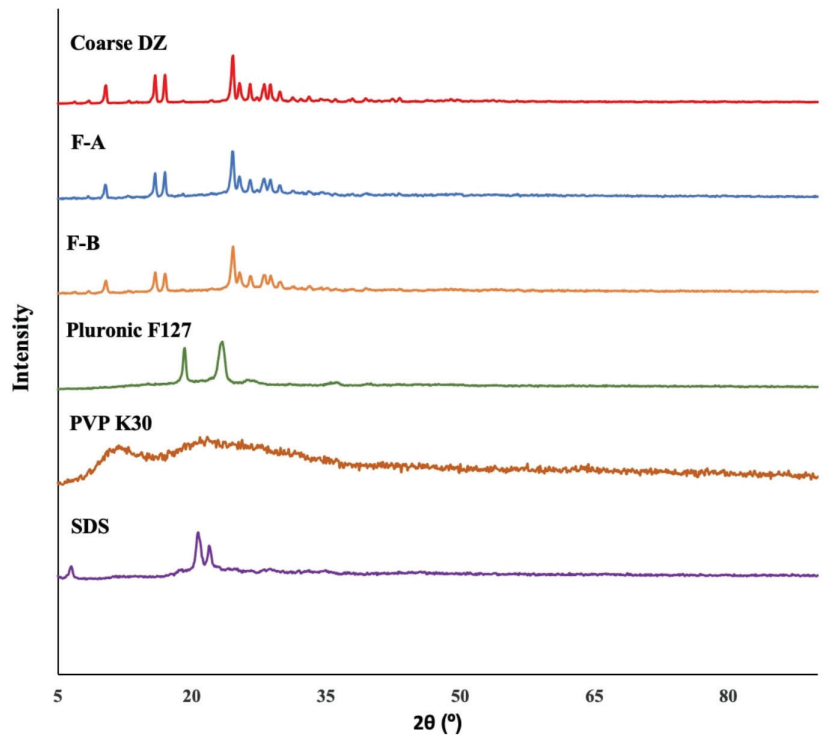

Figure 5. X-ray patterns of coarse DZ, F-A and F-B formulations, and the excipients in the formulation (pluronic F127, PVP K30, and SDS)

DZ: Daidzein, PVP: Polyvinylpyrrolidone, SDS: Sodium dodecyl sulfate

design the dissolution study. The solubility of coarse $\mathrm{DZ}$ in the buffer solutions $(\mathrm{HCl}-\mathrm{pH}$ 1.2; $\mathrm{PB}-\mathrm{pH}$ 6.8; and $\mathrm{PB}-\mathrm{pH}$ 7.4) with Tween $80(5 \%)$ was found to be $80.68 \pm 6.80 \mu \mathrm{g} /$ $\mathrm{mL}, 107.06 \pm 5.54 \mu \mathrm{g} / \mathrm{mL}$, and, $128.77 \pm 3.66 \mu \mathrm{g} / \mathrm{mL}$, respectively (Table 3). Furthermore, the solubility of DZ in F-A and F-B formulations was higher than that of coarse DZ ( $p<0.05$; Table 3).

\section{Dissolution studies of coarse DZ, F-A, and F-B formulations}

The dissolution studies of coarse DZ and nanosuspension formulations ( $\mathrm{F}-\mathrm{A}$ and $\mathrm{F}-\mathrm{B}$ ) were conducted in the different dissolution media $(\mathrm{HCl}+5 \%$ Tween $80-\mathrm{pH} 1.2 ; \mathrm{PB}+5 \%$ Tween $80-\mathrm{pH}$ 6.8, and 7.4), and the dissolution profiles for coarse DZ, $\mathrm{F}-\mathrm{A}$, and $\mathrm{F}-\mathrm{B}$ formulations are shown in Figure 6. $\ln \mathrm{HCl}+5 \%$ Tween 80 -pH 1.2, about 14\% (for coarse DZ), 65\% (for F-A), and $84 \%$ (for $\mathrm{F}-\mathrm{B}$ ) of $\mathrm{DZ}$ dissolved within 5 min. Besides, in PB + 5\% Tween $80-\mathrm{pH} 6.8$, and 7.4, 16\%-17\% (for coarse DZ), $66 \%-68 \%$ (for $F-A$ ) and, and $85 \%-86 \%$ (for F-B) of DZ dissolved within $5 \mathrm{~min}$. At $60^{\text {th }} \mathrm{min}$, about $60 \%$ (for coarse DZ) and $100 \%$ (for F-A and F-B) of DZ dissolved in all three dissolution media (Figure 6). As a result, it can be concluded that the dissolution of DZ can be improved and significantly increased by preparing a nanosuspension formulation of DZ. Wang et al. ${ }^{41}$ prepared and evaluated the nanosuspension formulations of $D Z$ using various stabilizers (soy lecithin, D-alpha-tocopherol polyethylene glycol 1000 succinate, hydroxypropyl- $\beta$-cyclodextrin, SDS, hydroxypropyl methylcellulose E5, sulfobutyl ether- $\beta$ cyclodextrin, or their combinations) to improve the solubility and oral bioavailability of DZ. They used the stabilizers to stabilize the small particles in a colloidal dispersion by electrostatic repulsion or steric hindrance to overcome the physical instability problem caused by small particle size and increased free energy in the colloidal dispersion. They reported that the DZ nanosuspension formulations with particle sizes of 360-600 nm and regular shapes. The authors also evaluated

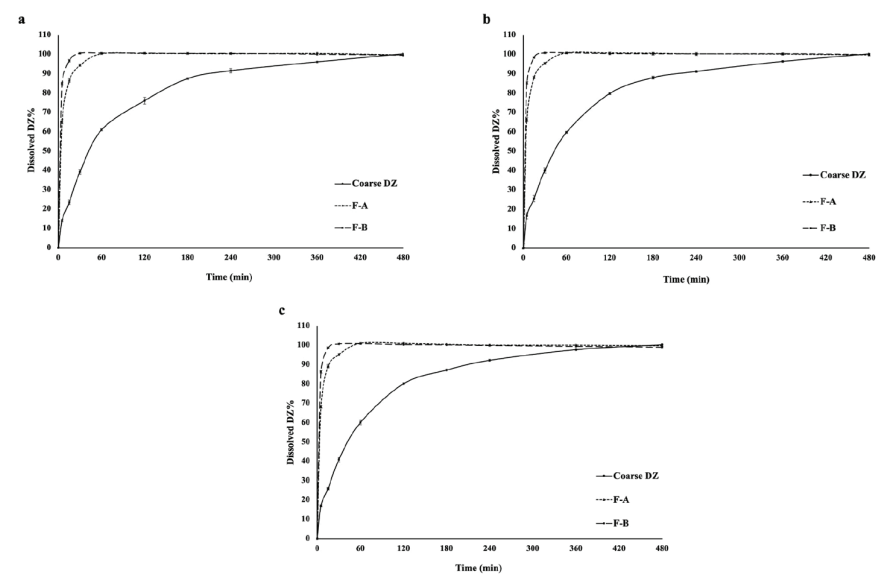

Figure 6. The dissolution profiles of coarse DZ, F-A and F-B formulations in the different dissolution media (a). $\mathrm{HCl}+5 \%$ Tween $80-\mathrm{pH}-1.2$; (b). PB + 5\% Tween 80 - pH-6.8; (c). PB + 5\% Tween 80 - pH-7.4 (mean \pm SE; $n=3$ ) DZ: Daidzein, PB: Phosphate buffer, SE: Standard error

the saturation solubility and the dissolution of coarse DZ and DZ nanosuspensions in distilled water and $900 \mathrm{~mL}$ of dissolution medium with $0.1 \%$ Tween- 80 , respectively. They found that the saturation solubility of crude DZ was very low (about $3 \mu \mathrm{g} / \mathrm{mL}$ ), however, the saturation solubility (about $8-21 \mu \mathrm{g} / \mathrm{mL}$ ) of $\mathrm{DZ}$ in nanosuspension formulations was higher than that of coarse DZ. Furthermore, they showed that less than $10 \%$ and $75 \%$ of coarse DZ dissolved in the dissolution medium with $0.1 \%$ Tween 80 within $5 \mathrm{~min}$ and $240 \mathrm{~min}$, respectively; however, more than $80 \%$ and $90 \%$ of DZ in nanosuspension formulations dissolved within $5 \mathrm{~min}$ and $240 \mathrm{~min}$, respectively. Because of the preparation of nanosuspension formulations of poorly soluble active substances/compounds, the particle surface area of these active substances/compounds increases significantly by reducing the particle size to the nanorange. The increased surface area provides a significant increase in the dissolution rate of the active substances/compounds according to NoyesWhitney equation. ${ }^{42}$ Additionally, the use of the appropriate amount of Tween-80 increases the dissolution rate of DZ.43

Moreover, Bhalla et al. ${ }^{21}$ Prepared co-crystals of DZ with isonicotinamide, theobromine, and cytosine by solvent-assisted grinding. They evaluated the solubility and intrinsic dissolution of co-crystals of DZ in PB - pH 6.8. They stated that co-crystals of DZ showed an almost 2-fold improvement in the solubility and dissolution of DZ compared to pure DZ.

\section{Cell culture study}

The cytotoxic effect of $D Z$ on cancer cells is dose-dependent. 17,44 In our study, the cytotoxic effects of DZ solution in the culture medium with $0.5 \% \mathrm{DMSO}$, and the suspensions of coarse $\mathrm{DZ}$, and the nanosuspension formulations (F-A and F-B) in culture medium on RG2 cell lines were evaluated using MTT assay. Control cells were treated with only a culture medium (C1) or a culture medium with $0.5 \%$ DMSO (C2). The maximum DMSO concentration to be used for cell culture studies should be $0.5 \% \cdot 17,45$ There was no significant difference in the cell viability between $\mathrm{C} 1$ and $\mathrm{C} 2$ for $24 \mathrm{~h}$ and $48 \mathrm{~h}$ incubation ( $p>0.05$; Figure 7 ). The cell viability was more than $93 \%$ after 
incubation with exp F-A or exp F-B for $24 \mathrm{~h}$ and $48 \mathrm{~h}$ incubation (Figure 7). This suggests that Exp F-A and Exp F-B exhibited no significant cytotoxicity compared to $\mathrm{C} 1(p>0.05)$. After 24 $\mathrm{h}$ and $48 \mathrm{~h}$ incubation, high concentrations (200 and $400 \mu \mathrm{M}$ ) of DZ solutions had a significant cytotoxic effect on RG2 cells compared to C2 $(p<0.05)$ and coarse DZ $(p<0.05)$. Besides, coarse DZ showed a cytotoxic effect on cancer cells at high concentrations (100-400 $\mu \mathrm{M} ; p<0.05$ compared to C1; Figure 7) for $24 \mathrm{~h}$ and $48 \mathrm{~h}$ incubation.

After $24 \mathrm{~h}$ and $48 \mathrm{~h}$ incubation, the results of the cytotoxicity study indicated that F-A and F-B caused a significant decrease in cell viability of RG2 cells at all concentrations ( $p<0.05$; except $400 \mu \mathrm{M}$ for DZ solution) compared to $\mathrm{C} 1$, coarse DZ, and DZ solution. After $24 \mathrm{~h}$ incubation, F-A and F-B formulations reduced the viability of RG2 cells by about $28 \%$ and $20 \%$ (at $50 \mu \mathrm{M}$ concentration) and by approximately $53 \%$ and $54 \%$ (at $400 \mu \mathrm{M}$ concentration), respectively (Figure 7). After $48 \mathrm{~h}$ incubation, the decrease in the viability of RG2 cells was approximately $48 \%$ (at $50 \mu \mathrm{M}$ concentration for both formulations $\mathrm{F}-\mathrm{A}$ and $\mathrm{F}-\mathrm{B}$ ) and about $67 \%$ (at $400 \mu \mathrm{M}$ concentration for both formulations F-A and F-B) (Figure 7). Coarse DZ, F-A and F-B formulations dose-dependently decreased RG2 cell viability.

\section{CONCLUSION}

a

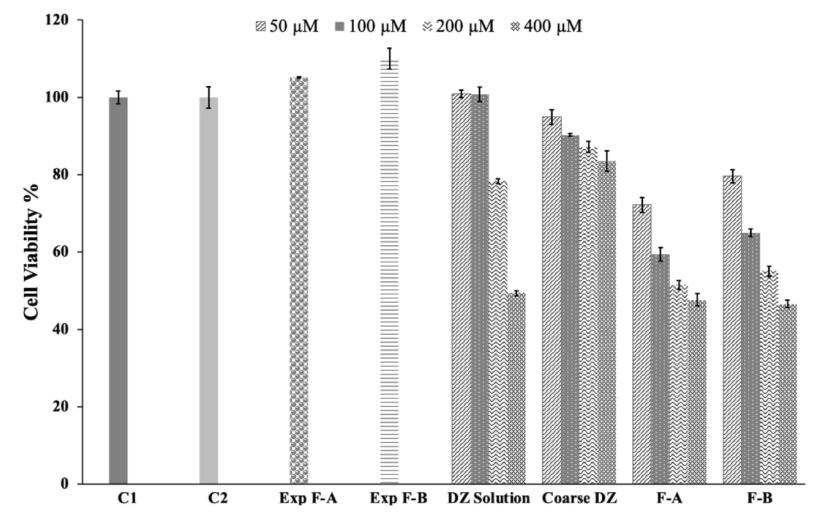

b

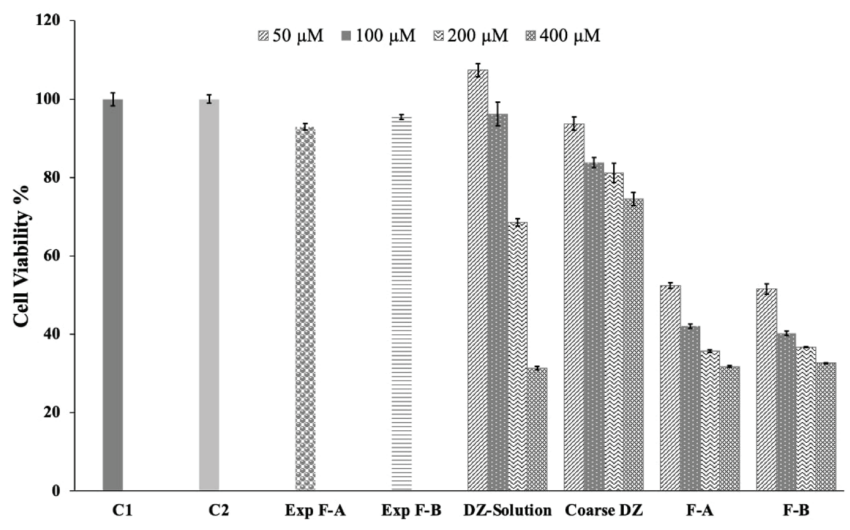

Figure 7. Cytotoxic effects of DZ solution, coarse $D Z$ and the nanosuspension formulations ( $F-A$ and $F-B$ ) for $24 \mathrm{~h}$ (a) and $48 \mathrm{~h}$ (b) incubation.

DZ: Daidzein
In our study, DZ nanosuspension formulations were successfully prepared and characterized in vitro. The results of characterization studies showed that the prepared nanosuspension formulations significantly increased the saturation solubility and dissolution rate of DZ as well as its cytotoxic effect on RG2 GBM tumor cells.

\section{ACKNOWLEDGMENTS}

We would like to thank Kerim Göğebakan and "Kar Kimya San. ve Tic. Ltd. Ști." for their assistance in providing zirconium oxide beads.

Conflict of interest: No conflict of interest was declared by the authors. The authors are solely responsible for the content and writing of this paper.

\section{REFERENCES}

1. Thadkala K, Nanam PK, Rambabu B, Sailu C, Aukunuru J. Preparation and characterization of amorphous ezetimibe nanosuspensions intended for enhancement of oral bioavailability. Int J Pharm Investig. 2014:4:131-137.

2. Junyaprasert VB, Morakul B. Nanocrystals for enhancement of oral bioavailability of poorly water-soluble drugs. Asian J Pharm Sci. 2015;10:13-23.

3. Wang $Y$, Zheng $Y$, Zhang $L$, Wang $Q$, Zhang D. Stability of nanosuspensions in drug delivery. J Control Release. 2013;172:1126-1141.

4. Jethara SI, Patel MR, Patel AD. Nano suspension drug delivery system: an overview. Aperito J Drug Design Pharmacol. 2014;1:106.

5. Savjani KT, Gajjar AK, Savjani JK. Drug solubility: importance and enhancement techniques. ISRN Pharm. 2012;2012:195727.

6. Patel HM, Patel BB, Shah CN. Nanosuspension: a novel approach to enhance solubility of poorly water soluble drugs - a review. Int J Adv Pharm. 2016:5:21-29.

7. Bektaş $A E$, Uğur $A B$, Çetin M. Nanosuspensions: preparation methods and stability Issue. Hacettepe Univ J Fac Pharm. 2018;38:85-101.

8. Verma S, Kumar S, Gokhale R, Burgess DJ. Physical stability of nanosuspensions: investigation of the role of stabilizers on Ostwald ripening. Int J Pharm. 2011;406:145-152.

9. Jacob S, Nair AB, Shah J. Emerging role of nanosuspensions in drug delivery systems. Biomater Res. 2020;24:3.

10. Ugur Kaplan AB, Cetin M, Orgul D, Taghizadehghalehjoughi A, Hacımuftuoglu A, Hekimoglu S. Formulation and in vitro evaluation of topical nanoemulsion and nanoemulsion-based gels containing daidzein. J Drug Deliv Sci Technol. 2019;52:189-203.

11. Ma Y, Zhao X, Li J, Shen Q. The comparison of different daidzein-PLGA nanoparticles in increasing its oral bioavailability. Int $\mathrm{J}$ Nanomedicine. 2012;7:559-570.

12. Gao Y, Gu W, Chen L, Xu Z, Li Y. The role of daidzein-loaded sterically stabilized solid lipid nanoparticles in therapy for cardio-cerebrovascular diseases. Biomaterials. 2008;29:4129-4136.

13. Zhang Z, Huang Y, Gao F, Bu H, Gu W, Li Y. Daidzein-phospholipid complex loaded lipid nanocarriers improved oral absorption: in vitro characteristics and in vivo behavior in rats. Nanoscale. 2011;3:1780-1787. 
14. Lo FH, Mak NK, Leung KN. Studies on the anti-tumor activities of the soy isoflavone daidzein on murine neuroblastoma cells. Biomed Pharmacother. 2007;61:591-595.

15. Guo JM, Kang GZ, Xiao BX, Liu DH, Zhang S. Effect of daidzein on cell growth, cell cycle, and telomerase activity of human cervical cancer in vitro. Int J Gynecol Cancer. 2004;14:882-888.

16. Siegelin MD, Gaiser T, Habel A, Siegelin Y. Daidzein overcomes TRAILresistance in malignant glioma cells by modulating the expression of the intrinsic apoptotic inhibitor, bcl-2. Neurosci Lett. 2009;454:223-228.

17. Gundogdu G, Dodurga Y, Cetin M, Secme M, Cicek B. The cytotoxic and genotoxic effects of daidzein on MIA PaCa-2 human pancreatic carcinoma cells and HT-29 human colon cancer cells. Drug Chem Toxicol. 2020;43:581-587.

18. Qiu F, Chen XY, Song B, Zhong DF, Liu CX. Influence of dosage forms on pharmacokinetics of daidzein and its main metabolite daidzein-7-Oglucuronide in rats. Acta Pharmacol Sin. 2005;26:1145-1152.

19. Borghetti GS, Pinto AP, Lula IS, Sinisterra RD, Teixeira HF, Bassani VL. Daidzein/cyclodextrin/hydrophilic polymer ternary systems. Drug Dev Ind Pharm. 2011;37:886-893.

20. Ge YB, Chen DW, Xie LP, Zhang RQ. Optimized preparation of daidzeinloaded chitosan microspheres and in vivo evaluation after intramuscular injection in rats. Int J Pharm. 2007;338:142-151.

21. Bhalla Y, Chadha K, Chadha R, Karan M. Daidzein cocrystals: an opportunity to improve its biopharmaceutical parameters. Heliyon. 2019;5:e02669.

22. Romano-Feinholz S, Salazar-Ramiro A, Muñoz-Sandoval E, MagañaMaldonado R, Hernández Pedro N, Rangel López E, González Aguilar A, Sánchez García A, Sotelo J, Pérez de la Cruz V, Pineda B. Cytotoxicity induced by carbon nanotubes in experimental malignant glioma. Int $\mathrm{J}$ Nanomed. 2017;12:6005-6026.

23. Danaei M, Dehghankhold M, Ataei S, Hasanzadeh Davarani F, Javanmard R, Dokhani A, Khorasani S, Mozafari MR. Impact of particle size and polydispersity index on the clinical applications of lipidic nanocarrier systems. Pharmaceutics. 2018;10:57.

24. Zhang X, Liu X, Zhang J, Zhou W, Lu J, Wang Q, Hu R. Daidzein derivative daid002 inhibits glioblastoma growth via disrupting the interaction between moesin and CD44. Oncotarget. 2018;5:1-12.

25. Patel VR, Agrawal YK. Nanosuspension: an approach to enhance solubility of drugs. J Adv Pharm Technol Res. 2011;2:81-87.

26. Attari Z, Kalvakuntla S, Reddy MS, Deshpande M, Rao CM, Koteshwara $\mathrm{KB}$. Formulation and characterisation of nanosuspensions of BCS class II and IV drugs by combinative method. J Exp Nanosci. 2016;11:276-288.

27. Sharma M, Mehta I. Surface stabilized atorvastatin nanocrystals with improved bioavailability, safety and antihyperlipidemic potential. Sci Rep. 2019;9:16105.

28. Shah U, Joshi G, Sawant K. Improvement in antihypertensive and antianginal effects of felodipine by enhanced absorption from PLGA nanoparticles optimized by factorial design. Mater Sci Eng C Mater Biol Appl. 2014:35:153-163.

29. Kandilli B, Ugur Kaplan AB, Cetin M, Taspinar N, Ertugrul MS, Aydin IC, Hacimuftuoglu A. Carbamazepine and levetiracetamloaded PLGA nanoparticles prepared by nanoprecipitation method: in vitro and in vivo studies. Drug Dev Ind Pharm. 2020;46:10631072.
30. Honary S, Zahir F. Effect of zeta potential on the properties of nano-drug delivery systems - a review (Part 2). Trop J Pharm Res. 2013;12:265-273.

31. Scheithauer EC, Li W, Ding Y, Harhaus L, Roether JA, Boccaccini AR. Preparation and characterization of electrosprayed daidzein-loaded PHBV microspheres. Mater Lett. 2015;158:66-69.

32. Daidzein, $>99 \%$ | LC laboratories. Accessed date: 14, 2021. Available from: https://lclabs.com/products/d-2946-daidzein

33. Huang Z, Xia J, Li J, Gao X, Wang Y, Shen Q. Optimization and bioavailability evaluation of self-microemulsifying drug delivery system of the daidzein-nicotinamide complex. RSC Advances. 2016;6:112686112694.

34. Kalvakuntla S, Deshpande M, Attari Z, Kunnatur B K. Preparation and characterization of nanosuspension of aprepitant by $\mathrm{H} 96$ process. Adv Pharm Bull. 2016;6:83-90

35. Panizzon GP, Giacomini Bueno F, Ueda-Nakamura T, Nakamura CV, Dias Filho BP. Manufacturing different types of solid dispersions of bcs class IV polyphenol (daidzein) by spray drying: formulation and bioavailability. Pharmaceutics. 2019;11:492.

36. The United States Convention. United States Pharmacopeia (USP 30NF25).; 2007.

37. Silva AP, Nunes BR, De Oliveira MC, Koester LS, Mayorga P, Bassani VL, Teixeira HF. Development of topical nanoemulsions containing the isoflavone genistein. Pharmazie. 2009;64:32-35.

38. Oliveira SR, Taveira SF, Marreto RN, Valadares MC, Diniz DGA, Lima EM. Preparation and characterization of solid oral dosage forms containing soy isoflavones. Rev Bras Farmacogn. 2013;23:175-181.

39. Argenta DF, de Mattos CB, Misturini FD, Koester LS, Bassani VL, Simões CM, Teixeira HF. Factorial design applied to the optimization of lipid composition of topical antiherpetic nanoemulsions containing isoflavone genistein. Int J Nanomed. 2014;9:4737-4747.

40. Wang Q, Liu W, Wang J, Liu H, Chen Y. Preparation and pharmacokinetic study of daidzein long-circulating liposomes. Nanoscale Res Lett. 2019;14:321.

41. Wang $H$, Xiao $Y$, Wang $H$, Sang $Z$, Han $X$, Ren $S$, Du $R$, Shi $X$, Xie $Y$. Development of daidzein nanosuspensions: preparation, characterization, in vitro evaluation, and pharmacokinetic analysis. Int J Pharm. 2019;566:67-76.

42. Yao J, Cui B, Zhao X, Wang Y, Zeng Z, Sun C, Yang D, Liu G, Gao J, Cui H. Preparation, characterization, and evaluation of azoxystrobin nanosuspension produced by wet media milling. Appl Nanosci. 2018;8:297-307.

43. Hu L, Zhang N, Yang G, Zhang J. Effects of tween-80 on the dissolution properties of daidzein solid dispersion in vitro. Int $\mathrm{J}$ Chem Int. J. Quantum Chem.. 2011;3(1):68-73.

44. Farjadian S, Khaioei Neiad L, Fazeli M, Askari Firouziaei H, Zaeri S. Doxorubicin cytotoxicity in combination with soy isoflavone daidzein on MCF-7 breast cancer cells. Mal J Nutr. 2015;21:67-73.

45. Pal R, Mamidi MK, Das AK, Bhonde R. Diverse effects of dimethyl sulfoxide (DMSO) on the differentiation potential of human embryonic stem cells. Arch Toxicol. 2012;86:651-661. 